\title{
Analisis Agroekosistem untuk Pengembangan Tanaman di Kota Kendari An Analysis of Agro Ecosystem for the Development of Crops in Kendari City
}

\author{
Oleh: \\ Syamsuddin Jufri ${ }^{1}$, Sahta Ginting ${ }^{2}$ dan La Ode Safuan ${ }^{2 *}$ \\ ${ }^{1}$ Alumni Program Studi Agronomi Program Pascasarjana UHO \\ ${ }^{2}$ Dosen Program Studi Agronomi Program Pascasarjana UHO
}

Diterima: 5 Agustus 2017/Disetujui: 7 Maret 2018

\begin{abstract}
Penelitian ini bertujuan untuk menganalisis untuk pengembangan tanaman di Kota Kendari, terdiri dari tanaman padi (Oryza sativa), jagung (Zea mays), sorghum (Shorgum bicolar), ubi kayu (Manihot esculenta), dan kacang tanah (Arachis hypogea). Penelitian ini telah dilaksanakan di Kota Kendari, analisis tanah dilaksanakan di Laboratorium Seameo Biotrop Bogor pada Bulan Desember 2014 sampai dengan Juli 2015. Kajian kondisi agroekosistem ini menggunakan beberapa analisis yaitu analisis iklim menggunakan metode klasifikasi Iklim Oldeman dan analisis kesesuaian iklim dan tanah terhadap tanaman menggunakan metode FAO pada tingkat kelas; dan analisis produksi tanaman terhadap kondisi iklim menggunakan metode regresi linear berganda. Hasil penelitian menunjukkan bahwa curah hujan di Kota Kendari berkisar 1.744-1.942 mm, rata-rata temperature udara $24-27^{\circ} \mathrm{C}$, dan kelembapan 81-95\%, dengan tipe iklim D3 and E2. Kesesuaian tanaman terhadap kondisi iklim berkisar antara sangat sesuai (S1) sampai dengan agak sesuai (S3), kesesuaian terhadap kondisi fisik dan kimia tanah berkisar antara sangat sesuai (S1) sampai dengan tidak sesuai (N2). Lahan di Kendari untuk budidaya tanaman direkomendasikan untuk pengembangan tanaman padi mencapai 13.219,93 ha, untuk jagung mencapai 10.753,60 ha, untuk sorghum mencapai 13.219,93 ha, untuk ubi kayu 13.689,41 ha, dan untuk kacang tanah 13.219,93 ha.
\end{abstract}

Keywords: Agroekosistim, curah hujan,, evaluasi laha, iklim, , kelembapan udara, temperature udara

\begin{abstract}
This study aimed to analyze the agro ecosystem condition for the development of crops in Kendari city, which includes upland rice (Oryza sativa), maize (Zea mays), sorghum (Shorgum bicolar), cassava (Manihot esculenta), and peanuts (Arachis hypogea). The study was conducted in Kendari city, where as soil analysis was carried out at Seameo Biotrop Service Laboratory in Bogor from December 2014 to July 2015. The agro ecosystem condition was studied through several forms of analysis, the are an analysis of climate characteristics by using the simple average method, IDW interpolation method, and Oldeman climate clarification method; an analysis of climate and soil suitability for plants by using FAO method at class level. The results of the study show that rainfall in Kendari City ranged between 1.744$1.942 \mathrm{~mm}$, the average air temperature was between $24-27^{\circ} \mathrm{C}$, and humidity between $81-95 \%$, with climate type of D3 and E2. The level of crop suitability to climate condition ranged between highly suitable (S1) to moderately suitable (S3), where as the suitability to physical, chemical, and condition of soil slope was also between highly suitable (S1) to forever unsuitable (N2). Lands in Kendari City that at manageable or recommended for cultivation of upland rice were up to $13.219,93$ ha, for cultivation of maize was up to $10.753,60$ ha, for sorgum $13.219,93$ ha, for cassava $13.689,41$ ha, and for peanut $13.219,93$ ha.
\end{abstract}

Keywords: Agroecosystem, air humidity, air temperature, climate, , land evaluation, rainfall

\footnotetext{
${ }^{*}$ Penulis untuk korespondensi. Email e-mail: safuan65@yahoo.co.id
} 


\section{J. Berkala Penelitian Agronomi 6 (1) : 9-16 (2018)}

\section{PENDAHULUAN}

Pembangunan

pertanian yang

berkelanjutan merupakan suatu konsep efektif yang dapat mempertahankan keberlanjutan sistem budidaya per-tanian pada suatu daerah. Tetapi, konsep budidaya pertanian yang berkembang saat ini masih jauh dari konteks pertanian yang berkelanjutan, sehingga hasil produksi tidak maksimal dan sistem budidaya tidak berlangsung sepanjang tahun. Konsep pembangunan per-taninan yang berkelanjutan harus memperhatikan kondisi wilayah pengembangan. Kondisi wilayah ini tiada lain adalah faktor yang mem-pengaruhi pertumbuhan tanaman, meliputi iklim dan tanah. Iklim memiliki peranan yang sangat penting dalam pertumbuhan tanaman. Menurut Suciantini (2015) bahwa salah satu komponen lingkungan yang merupakan faktor penentu keber-hasilan suatu usaha budidaya tanaman adalah iklim/cuaca. Interaksi antara iklim/cuaca sebagai faktor lingkungan dengan faktor genetik tanaman akan berpengaruh terhadap pertumbuhan dan kualitas tanaman. Tjasyono (1999; 2004), menyatakan bahwa di dalam pertanian, kehutanan, dan perkebunan pemeliharaan pertama terhadap tanaman yang baru tumbuh adalah sangat penting karena tanaman muda masih lunak terutama peka terhadap kondisi iklim. Karena itu sebelum memperhatikan tanaman muda, perlu mengetahui lebih dulu iklim setempat agar dapat dicapai hasil yang maksimal. Tjasyono (2004), juga menya-takan bahwa cuaca dan iklim merupakan salah satu peubah dalam produksi pangan yang sukar dikendalikan. Oleh karena itu dalam usaha pertanian, pada umumnya cara-cara bertani disesuaikan dengan kondisi iklim setempat. Selain kondisi iklim, kondisi tanah juga mem-pengaruhi pertumbuhan tanaman. Tanah yang memiliki tingkat kesuburan yang tinggi akan berdam-pak pada pertumbuhan tanaman yang optimal. Kesuburan tanah meliputi kesuburan fisik, kimia, dan biologi. Analisis agroklimat merupakan salah satu pendekatan yang dapat ditempuh untuk menilai iklim atau unsur-unsur iklim terhadap tanaman. Analisis agroklimat dimaksudkan untuk menilai kesesuaian tanaman dengan kondisi iklim pada suatu daerah pengembangan. Sedangkan untuk analisis klasifikasi iklimnya menggunakan metode klasifikasi iklim menurut Oldeman, karena tanaman yang ingin dianalisis adalah tanaman jenis tanaman pangan. Selain itu, memperhatikan kondisi air tanah juga sangat penting. Keberhasilan suatu kegiatan pertanian sangat ditentukan oleh perimbangan antara jumlah air yang tersedia di lahan dengan jumlah air yang dibutuhkan tanaman selama masa pertumbuhannya (Hidayat et al, 2006). Untuk menilai kondisi air tanah dapat dilakukan dengan analisis neraca air lahan dengan memper-hatikan air yang masuk ke tanah dalam bentuk presipitasi (air hujan) dengan air yang kembali ke atmosfer melalui evaporasi dan transpirasi atau evapotranspirasi. Menurut Djufry (2012), keunggulan teknologi pemodelan neraca air adalah dapat dimanfaatkan untuk memprediksi potensi hasil tanaman secara akurat, prediksi kadar air tanah, dan penentuan waktu tanam optimum pada suatu daerah/wilayah. Keberhasilan pengembangan komoditas pertanian yang ingin dikembangkan tergantung pula pada pemilihan komoditas yang tepat. Pemilihan komoditas ini harus mempertimbangkan komoditas yang sudah menjadi unggulan di daerah pengem-bangan atau sudah dilakukan pem-budidayaan sebelumnya. Hal ini dimaksudkan agar mendapat gambaran perkembangan produktivitas setiap tahunnya. Kota Kendari memiliki prospek untuk pengembangan budidaya per-tanian khususnya tanaman pangan. Hal ini terlihat jelas pada hasil produksi pertanian tanaman pangan di Kota Kendari, dimana hasil produksi padi sawah 38,93 kuintal/ha, jagung 25,89 kuintal/ha, ubi kayu 198,76 kuintal/ha, ubi jalar 82,52 kuintal/ha, kacang kedelai 8,84 kuintal/ha dan kacang tanah 6,12 kuintal/ha (Dinas Pertanian dan Kehutanan Kota Kendari). Pencapaian hasil produksi ini masih tergolong rendah sehingga dipandang perlu dilakukan analisis lebih lanjut mengenai komoditas yang sudah diusahakan pada wilayah pengembangan serta komoditas yang dipandang toleran seperti tanaman padi gogo dan sorgum. Menganalisis daerah pengembangan pertanian dalam skala yang luas 


\section{J. Berkala Penelitian Agronomi 6 (1) : 9-16 (2018)}

diperlukan penggunaan softwere pengolahan ber-basis geografis (spasial). Softwere analisis geografis information system (GIS) sudah sering digunakan dalam hal analisis daerah pengembangan, khususnya dibidang pertanian. Peng-gunaan Softwere analisis ini dimaksudkan untuk memudahkan dalam proses analisis. Tujuan yang ingin dicapai pada penelitian ini adalah untuk mengkaji tingkat kesesuaian agroekosistem yang untuk pengem-bangan tanaman padi gogo, jagung, sorgum, ubi kayu dan kacang tanah di Kota Kendari.

\section{BAHAN DAN METODE}

Penelitian ini dilaksanakan di Kota Kendari dan di Laboratorium Seameo Biotrop Service Laboratory Bogor pada bulan Desember 2014 sampai Mei 2015. Bahanbahan yang digunakan dalam penelitian ini adalah Data primer adalah data yang di-peroleh dari pengamatan langsung di lapangan, pengambilan sampel tanah, dan cek lapangan (ground check). Data skunder yaitu data yang diperoleh dari instansi terkait yang terdiri dari: Data iklim (suhu, curah hujan, dan kelembaban) dari stasiun BMKG di wilayah Kota Kendari yaitu Stasiun Meteorologi Maritim Kendari dan Stasiun Geofisika Kendari, dan dari BPTP Sulawesi Tenggara selama 12 tahun terakhir (2003-2014), Peta RBI dari BIG, DEM SRTM $90 \mathrm{~m}$ dari CGIAR CSI, Peta Penutupan Lahan Kota Kendari dari Dinas Tata Ruang Kota Kendari, Peta

\section{HASIL}

Hasil klasifikasi iklim menggunakan metode klasifikasi iklim Oldeman dapat dikatakan bahwa di Stasiun Meteorologi Maritim Kendari tergolong tipe iklim. Hal ini disebabkan karena terdapat empat periode bulan basah yang berlangsung secara berturut-turut dan empat peride bulan kering. Kondisi ini sama dengan
Administrasi Kota Kendari dari Dinas Tata Ruang Kota Kendari, Peta Kawasan Hutan Kota Kendari dari BIPHUT Provinsi Sulawesi Tenggara, Data syarat tum-buh tanaman dari studi pustaka, Data kondisi aktual wilayah Kota Kendari dari citra satelit. Alat-alat yang di-gunakan dalam penelitian ini adalah Seperangkat komputer (laptop) yang terdiri dari perangkat keras dan perangkat lunak untuk masukan data, pengolahan data, dan keluaran data (perangkat keras berupa laptop dengan procesor Intel Pentium Dual Core T340 @ 2,16 $\mathrm{GHz} 996 \mathrm{MHz}$ kapasitas harddisk $160 \mathrm{~GB}$, RAM 896 MB, dan perinter untuk mencetak, perangkat lunak yang dipakai adalah softwere Arcviuw GIS 3.3 dan softwere Microsoft Office Excel 2003 untuk mengolah data iklim), alat survey yaitu kendaraan roda dua dan Global Positioning System (GPS), parang/arit untuk membersihkan semak belukar di lokasi pengambilan sampel tanah, pacul untuk menggali tanah sampel, ring sampel 10 buah, alat dokumentasi berupa digital camera, dan alat tulis menulis. Kajian kondisi agroekosistem ini menggunakan beberapa analisis yaitu analisis iklim menggunakan metode klasifikasi Iklim Oldeman dan analisis kesesuaian iklim dan tanah terhadap tanaman menggunakan metode FAO pada tingkat kelas; dan analisis produksi tanaman terhadap kondisi iklim menggunakan metode regresi linear berganda.

di Stasiun Geofisika Kendari. Berbeda halnya dengan lokasi BPTP Sulawesi Tenggara, terdapat dua periode bulan basah secara berturut-turut dan tiga periode bulan kering. Dari kriteria Tipe iklim Oldeman tergolong pada iklim E2 (Tabel 1).

Tabel 1. Tipe Iklim di Kota Kendari berdasarkan Klasifikasi Iklim Oldeman

\begin{tabular}{lccc}
\hline \multicolumn{1}{c}{ Lokasi } & Bulan Basah & Bulan Kering & Tipe Iklim \\
\hline $\begin{array}{l}\text { Stasiun Meteorologi } \\
\text { Maritim Kendari }\end{array}$ & 4 bulan & 4 bulan & D3 \\
Stasiun Geofisika Kendari & 4 bulan & 4 bulan & D3 \\
BPTP Sulawesi Tenggara & 2 bulan & 3 bulan & E2 \\
\hline sumber: hasil analisis curah hujan di Stasiun Meteorologi Maritim Kendari, Stasiun Geofisika \\
\multicolumn{2}{c}{ Kendari dan BPTP Sulawesi Tenggara tahun 2003 s/d 2014 }
\end{tabular}


Hasil pengamatan kondisi agroekosistem di Kecamatan Baruga, Puuwatu, dan Kendari menunjukkan nilai kesesuaian sangat sesuai hingga tidak sesuai. Pada kondisi aktual di Kecamatan Baruga pada unit lahan 9 menunjukkan tingkat kesesuaian agak sesuai hingga tidak sesuai saat ini. Sedangkan pada kondisi potensial menunjukkan tingkat kesesuaian sangat sesuai hingga sesuai. Faktor lingkungan yang menjadi pembatas pada kondisi aktual adalah curah hujan, kelembaban udara, suhu udara, $\mathrm{pH}$ tanah, $\mathrm{N}$ total, $\mathrm{P}_{2} \mathrm{O}_{5}$ dan KTK tanah (Tabel 2) Kondisi aktual di Kecamatan Baruga pada unit lahan 10 menunjukkan kesesuaian agak sesuai hingga tidak sesuai saat ini. sedangkan pada kondisi potensial menunjukkan tingkat kesesuaian sesuai. Faktor lingkungan yang menjadi pembatas pada kondisi aktual adalah curah hujan, kelembaban udara, suhu udara, $\mathrm{pH}$ tanah, bahan organik, $\mathrm{N}$ total, $\mathrm{P}_{2} \mathrm{O}_{5}, \mathrm{KTK}$ tanah, dan kelerengan sedangkan faktor lingkungan yang menjadi pembatas pada kondisi potensial adalah curah hujan, kelembaban udara, dan suhu udara. Lebih jelanya disajikan pada Tabel 3. Kondisi aktual di Kecamatan Puuwatu pada unit lahan 26 menunjukkan tingkat kesesuaian sesuai. sedangkan pada kondisi potensial menunjukkan tingkat kesesuaian sangat sesuai hingga sesuai. Faktor lingkungan yang menjadi pembatas pada kondisi aktual adalah curah hujan, bulan kering, kelembaban udara, suhu udara, pH tanah, $\mathrm{N}$ total, KTK tanah, dan kelerengan sedangkan faktor lingkungan yang menjadi pembatas pada kondisi potensial adalah curah hujan, bulan kering, kelembaban udara, dan suhu udara. Lebih jelanya disajikan pada Tabel 4. Kondisi aktual di Kecamatan Puuwatu pada unit lahan 27 menunjukkan tingkat kesesuaian sesuai, sedangkan pada kondisi potensial menunjukkan tingkat kesesuaian sangat sesuai hingga sesuai. Faktor lingkungan yang menjadi pembatas pada kondisi aktual adalah curah hujan, bulan kering, kelembaban udara, suhu udara, $\mathrm{pH}$ tanah, $\mathrm{N}$ total, KTK tanah, dan kelerengan sedangkan faktor lingkungan yang menjadi pembatas pada kondisi potensial adalah curah hujan, bulan kering, kelembaban udara, dan suhu udara. Lebih jelasnya disajikan pada Tabel 5. Kondisi aktual di Kecamatan Kendari pada unit lahan 1 menunjukkan tingkat kesesuaian sesuai hingga agak sesuai. sedangkan pada kondisi potensial menunjukkan tingkat kesesuaian sangat sesuai hingga sesuai. Faktor lingkungan yang menjadi pembatas pada kondisi aktual adalah curah hujan, bulan kering, kelembaban udara, dan $\mathrm{pH}$ tanah sedangkan faktor lingkungan yang menjadi pembatas pada kondisi potensial adalah curah hujan, bulan kering, dan kelembaban udara. Lebih jelasnya disajikan pada Tabel 6.

Tabel 2. Kesesuaian agroklimat dan tanah di Kecamatan Baruga pada unit lahan 9

\begin{tabular}{lcccccc}
\hline \multirow{2}{*}{ Faktor Lingkungan } & \multirow{2}{*}{ Nilai } & \multicolumn{5}{c}{ Tanaman } \\
\cline { 3 - 6 } & & $\mathrm{T} 1$ & $\mathrm{~T} 2$ & $\mathrm{~T} 3$ & $\mathrm{~T} 4$ & $\mathrm{~T} 5$ \\
\hline Curah Hujan/tahun $(\mathrm{mm})$ & $1.766-1.875$ & $\mathrm{~S} 1$ & $\mathrm{~S} 1$ & $\mathrm{~S} 2$ & $\mathrm{~S} 1$ & $\mathrm{~S} 1$ \\
Bulan Kering/tahun & 4 & $\mathrm{~S} 1$ & $\mathrm{~S} 1$ & $\mathrm{~S} 1$ & $\mathrm{~S} 1$ & $\mathrm{~S} 1$ \\
Kelembaban Udara $(\%)$ & $81-85$ & $\mathrm{~S} 1$ & $\mathrm{~S} 1$ & $\mathrm{~S} 2$ & & $\mathrm{~S} 2$ \\
Suhu Udara $\left({ }^{\circ} \mathrm{C}\right)$ & $26,5-27,0$ & $\mathrm{~S} 1$ & $\mathrm{~S} 2$ & $\mathrm{~S} 1$ & $\mathrm{~S} 1$ & $\mathrm{~S} 1$ \\
$\mathrm{pH}$ & 4,8 & $\mathrm{~S} 1$ & $\mathrm{~S} 3$ & $\mathrm{~N} 1$ & $\mathrm{~S} 3$ & $\mathrm{~S} 3$ \\
$\mathrm{C}$ Organik $(\%)$ & $0,345($ sangat rendah) & $\mathrm{S} 2$ & $\mathrm{~S} 2$ & $\mathrm{~S} 2$ & $\mathrm{~S} 2$ & $\mathrm{~S} 2$ \\
$\mathrm{~N}$ Total $(\%)$ & 0,04 (sangat rendah) & $\mathrm{S} 3$ & $\mathrm{~S} 2$ & $\mathrm{~S} 3$ & & $\mathrm{~S} 3$ \\
Rasio C/N & 6 (sangat rendah) & $\mathrm{S} 3$ & $\mathrm{~N} 1$ & $\mathrm{~S} 3$ & & $\mathrm{~S} 3$ \\
$\mathrm{P}_{2} \mathrm{O}_{5}$ Potensial $(\mathrm{mg} / 100 \mathrm{~g})$ & 79 (sangat tinggi) & $\mathrm{S} 1$ & $\mathrm{~S} 1$ & $\mathrm{~S} 1$ & & $\mathrm{~S} 1$ \\
$\mathrm{~K}_{2} \mathrm{O}$ Potensial $(\mathrm{mg} / 100 \mathrm{~g})$ & 3,29 (sangat rendah) & $\mathrm{S} 3$ & $\mathrm{~S} 3$ & $\mathrm{~S} 3$ & $\mathrm{~S} 2$ & $\mathrm{~S} 3$ \\
KTK (cmol/kg) & $0-3 \%$ & $\mathrm{~S} 1$ & $\mathrm{~S} 1$ & $\mathrm{~S} 1$ & $\mathrm{~S} 1$ & $\mathrm{~S} 1$ \\
Kelerengan & $1.766-1.875$ & $\mathrm{~S} 1$ & $\mathrm{~S} 1$ & $\mathrm{~S} 2$ & $\mathrm{~S} 1$ & $\mathrm{~S} 1$ \\
\hline Kondisi lahan aktual & & $\mathrm{S} 3$ & $\mathrm{~N} 1$ & $\mathrm{~N} 1$ & $\mathrm{~S} 3$ & $\mathrm{~S} 3$ \\
\hline Kondisi lahan potensial & & $\mathrm{S} 1$ & $\mathrm{~S} 2$ & $\mathrm{~S} 2$ & $\mathrm{~S} 1$ & $\mathrm{~S} 2$ \\
\hline
\end{tabular}

Sumber : Hasil analisis 2015

Keterangan : $\quad$ T1=Padi gogo, T2=Jagung, T3=Sorgum, T4=Ubi kayu, T5=Kacang tanah S1=Sangat sesuai, S2=Sesuai, S3=Agak sesuai, N1=Tidak sesuai saat ini $\mathrm{N} 2=$ Tidak sesuai selamanya 
J. Berkala Penelitian Agronomi 6 (1) : 9 - 16 (2018)

Tabel 3. Kesesuaian agroklimat dan tanah di Kecamatan Baruga pada unit lahan 10

\begin{tabular}{|c|c|c|c|c|c|c|}
\hline \multirow{2}{*}{ Faktor Lingkungan } & \multirow{2}{*}{ Nilai } & \multicolumn{5}{|c|}{ Tanaman } \\
\hline & & $\mathrm{T} 1$ & $\mathrm{~T} 2$ & T3 & $\mathrm{T} 4$ & T5 \\
\hline Curah Hujan/tahun (mm) & $1.766-1.897$ & S1 & S1 & $\mathrm{S} 2$ & S1 & S1 \\
\hline Bulan Kering/tahun & 4 & S1 & S1 & S1 & S1 & S1 \\
\hline Kelembaban Udara $(\%)$ & $81-85$ & S1 & S1 & S2 & & $\mathrm{S} 2$ \\
\hline Suhu Udara $\left({ }^{0} \mathrm{C}\right)$ & $26,0-27,0$ & S1 & S2 & $\mathrm{S} 1$ & $\mathrm{~S} 1$ & S1 \\
\hline $\mathrm{pH}$ & 4,7 & S1 & $\mathrm{S} 3$ & N1 & S3 & S3 \\
\hline C Organik (\%) & 0,445 (sangat rendah) & S2 & S2 & $\mathrm{S} 2$ & S2 & $\mathrm{S} 2$ \\
\hline N Total $(\%)$ & 0,065 (sangat rendah) & S3 & S3 & S3 & & $\mathrm{S} 2$ \\
\hline Rasio C/N & 11 (rendah) & $\mathrm{S} 2$ & S3 & $\mathrm{S} 2$ & & $\mathrm{~S} 2$ \\
\hline $\mathrm{P}_{2} \mathrm{O}_{5}$ Potensial $(\mathrm{mg} / 100 \mathrm{~g})$ & 102 (sangat tinggi) & S1 & S1 & S1 & & $\mathrm{S} 1$ \\
\hline $\mathrm{K}_{2} \mathrm{O}$ Potensial $(\mathrm{mg} / 100 \mathrm{~g})$ & 3,59 (sangat rendah) & S3 & S3 & S3 & S2 & S3 \\
\hline $\mathrm{KTK}(\mathrm{cmol} / \mathrm{kg})$ & $3-8 \%$ & S2 & S2 & $\mathrm{S} 2$ & S1 & $\mathrm{S} 2$ \\
\hline Kelerengan & $1.766-1.897$ & S1 & S1 & $\mathrm{S} 2$ & $\mathrm{~S} 1$ & S1 \\
\hline Kondisi lahan aktual & & S3 & S3 & N1 & S3 & S3 \\
\hline Kondisi lahan potensial & & S2 & S2 & $\mathrm{S} 2$ & S1 & S2 \\
\hline \multicolumn{7}{|l|}{ Sumber : Hasil analisis 2015} \\
\hline $\begin{array}{ll}\text { Keterangan : } & \text { T1=Padi gogo, } \\
\text { S1=Sangat sesu } \\
\text { N2=Tidak sesu }\end{array}$ & $\begin{array}{l}\text { Jagung, T3=Sorgum, T4=l } \\
2=\text { Sesuai, S3=Agak sesua } \\
\text { lamanya }\end{array}$ & & & & & \\
\hline
\end{tabular}

Tabel 4. Kesesuaian agroklimat dan tanah di Kecamatan Puuwatu pada unit lahan 26

\begin{tabular}{lcccccc}
\hline \multirow{2}{*}{ Faktor Lingkungan } & \multirow{2}{*}{ Nilai } & \multicolumn{5}{c}{ Tanaman } \\
\cline { 2 - 6 } & & $\mathrm{T} 1$ & $\mathrm{~T} 2$ & $\mathrm{~T} 3$ & $\mathrm{~T} 4$ & $\mathrm{~T} 5$ \\
\hline Curah Hujan/tahun $(\mathrm{mm})$ & $1.766-1.897$ & $\mathrm{~S} 1$ & $\mathrm{~S} 1$ & $\mathrm{~S} 2$ & $\mathrm{~S} 1$ & $\mathrm{~S} 1$ \\
Bulan Kering/tahun & 3 & $\mathrm{~S} 1$ & $\mathrm{~S} 1$ & $\mathrm{~S} 2$ & $\mathrm{~S} 1$ & $\mathrm{~S} 1$ \\
Kelembaban Udara $(\%)$ & $81-85$ & $\mathrm{~S} 1$ & $\mathrm{~S} 1$ & $\mathrm{~S} 2$ & & $\mathrm{~S} 2$ \\
Suhu Udara $\left({ }^{\circ} \mathrm{C}\right)$ & $26,0-27,0$ & $\mathrm{~S} 1$ & $\mathrm{~S} 2$ & $\mathrm{~S} 1$ & $\mathrm{~S} 1$ & $\mathrm{~S} 1$ \\
$\mathrm{pH}$ & 5,8 & $\mathrm{~S} 1$ & $\mathrm{~S} 2$ & $\mathrm{~S} 2$ & $\mathrm{~S} 1$ & $\mathrm{~S} 2$ \\
$\mathrm{C}$ Organik $(\%)$ & 1,29 (rendah) & $\mathrm{S} 1$ & $\mathrm{~S} 1$ & $\mathrm{~S} 1$ & $\mathrm{~S} 1$ & $\mathrm{~S} 1$ \\
$\mathrm{~N}$ Total $(\%)$ & 0,175 (rendah) & $\mathrm{S} 2$ & $\mathrm{~S} 2$ & $\mathrm{~S} 2$ & & $\mathrm{~S} 2$ \\
Rasio C/N & $147,5($ sangat tinggi) & $\mathrm{S} 1$ & $\mathrm{~S} 1$ & $\mathrm{~S} 1$ & & $\mathrm{~S} 1$ \\
$\mathrm{P}_{2} \mathrm{O}_{5}$ Potensial $(\mathrm{mg} / 100 \mathrm{~g})$ & $183($ sangat tinggi) & $\mathrm{S} 1$ & $\mathrm{~S} 1$ & $\mathrm{~S} 1$ & & $\mathrm{~S} 1$ \\
$\mathrm{~K}_{2} \mathrm{O}$ Potensial $(\mathrm{mg} / 100 \mathrm{~g})$ & $13,745($ rendah) & $\mathrm{S} 2$ & $\mathrm{~S} 2$ & $\mathrm{~S} 2$ & $\mathrm{~S} 2$ & $\mathrm{~S} 2$ \\
KTK (cmol/kg) & $3-8 \%$ & $\mathrm{~S} 2$ & $\mathrm{~S} 2$ & $\mathrm{~S} 2$ & $\mathrm{~S} 1$ & $\mathrm{~S} 2$ \\
Kelerengan & $1.766-1.897$ & $\mathrm{~S} 1$ & $\mathrm{~S} 1$ & $\mathrm{~S} 2$ & $\mathrm{~S} 1$ & $\mathrm{~S} 1$ \\
\hline Kondisi lahan aktual & & $\mathrm{S} 2$ & $\mathrm{~S} 2$ & $\mathrm{~S} 2$ & $\mathrm{~S} 2$ & $\mathrm{~S} 2$ \\
\hline Kondisi lahan potensial & & $\mathrm{S} 1$ & $\mathrm{~S} 2$ & $\mathrm{~S} 2$ & $\mathrm{~S} 1$ & $\mathrm{~S} 2$ \\
\hline
\end{tabular}

Sumber : Hasil analisis 2015

Keterangan : T1=Padi gogo, T2=Jagung, T3=Sorgum, T4=Ubi kayu, T5=Kacang tanah $\mathrm{S} 1=$ Sangat sesuai, $\mathrm{S} 2=$ =Sesuai, $\mathrm{S} 3=$ Agak sesuai, N1=Tidak sesuai saat ini $\mathrm{N} 2=$ Tidak sesuai selamanya 
J. Berkala Penelitian Agronomi 6 (1) : 9 - 16 (2018)

Tabel 5. Kesesuaian Agroklimat dan Tanah di Kecamatan Puuwatu pada unit lahan 27

\begin{tabular}{lcccccc}
\hline \multirow{2}{*}{ Faktor Lingkungan } & \multirow{2}{*}{ Nilai } & \multicolumn{5}{c}{ Tanaman } \\
\cline { 3 - 6 } & & $\mathrm{T} 1$ & $\mathrm{~T} 2$ & $\mathrm{~T} 3$ & $\mathrm{~T} 4$ & $\mathrm{~T} 5$ \\
\hline Curah Hujan/tahun $(\mathrm{mm})$ & $1.744-1.831$ & $\mathrm{~S} 1$ & $\mathrm{~S} 1$ & $\mathrm{~S} 2$ & $\mathrm{~S} 1$ & $\mathrm{~S} 1$ \\
Bulan Kering/tahun & 3 & $\mathrm{~S} 1$ & $\mathrm{~S} 1$ & $\mathrm{~S} 2$ & $\mathrm{~S} 1$ & $\mathrm{~S} 1$ \\
Kelembaban Udara $(\%)$ & $81-85$ & $\mathrm{~S} 1$ & $\mathrm{~S} 1$ & $\mathrm{~S} 2$ & & $\mathrm{~S} 2$ \\
$\mathrm{Suhu}$ Udara $\left({ }^{\circ} \mathrm{C}\right)$ & $26,0-27,0$ & $\mathrm{~S} 1$ & $\mathrm{~S} 2$ & $\mathrm{~S} 1$ & $\mathrm{~S} 1$ & $\mathrm{~S} 1$ \\
$\mathrm{pH}$ & 6,6 & $\mathrm{~S} 2$ & $\mathrm{~S} 1$ & $\mathrm{~S} 1$ & $\mathrm{~S} 1$ & $\mathrm{~S} 1$ \\
$\mathrm{C}$ Organik $(\%)$ & 1,165 (rendah) & $\mathrm{S} 1$ & $\mathrm{~S} 1$ & $\mathrm{~S} 1$ & $\mathrm{~S} 1$ & $\mathrm{~S} 1$ \\
$\mathrm{~N}$ Total $(\%)$ & 0,165 (rendah) & $\mathrm{S} 2$ & $\mathrm{~S} 2$ & $\mathrm{~S} 2$ & & $\mathrm{~S} 2$ \\
Rasio C/N & $87,5($ sangat tinggi) & $\mathrm{S} 1$ & $\mathrm{~S} 1$ & $\mathrm{~S} 1$ & & $\mathrm{~S} 1$ \\
$\mathrm{P}_{2} \mathrm{O}_{5}$ Potensial $(\mathrm{mg} / 100 \mathrm{~g})$ & $149($ sangat tinggi) & $\mathrm{S} 1$ & $\mathrm{~S} 1$ & $\mathrm{~S} 1$ & & $\mathrm{~S} 1$ \\
$\mathrm{~K}_{2} \mathrm{O}$ Potensial $(\mathrm{mg} / 100 \mathrm{~g})$ & 12,3 (rendah) & $\mathrm{S} 2$ & $\mathrm{~S} 2$ & $\mathrm{~S} 2$ & $\mathrm{~S} 2$ & $\mathrm{~S} 2$ \\
$\mathrm{KTK}(\mathrm{cmol} / \mathrm{kg})$ & $3-8 \%$ & $\mathrm{~S} 2$ & $\mathrm{~S} 2$ & $\mathrm{~S} 2$ & $\mathrm{~S} 1$ & $\mathrm{~S} 2$ \\
Kelerengan & $1.744-1.831$ & $\mathrm{~S} 1$ & $\mathrm{~S} 1$ & $\mathrm{~S} 2$ & $\mathrm{~S} 1$ & $\mathrm{~S} 1$ \\
\hline Kondisi lahan aktual & & $\mathrm{S} 2$ & $\mathrm{~S} 2$ & $\mathrm{~S} 2$ & $\mathrm{~S} 2$ & $\mathrm{~S} 2$ \\
\hline Kondisi lahan potensial & & $\mathrm{S} 1$ & $\mathrm{~S} 2$ & $\mathrm{~S} 2$ & $\mathrm{~S} 1$ & $\mathrm{~S} 2$ \\
\hline Sumber $:$ Hasil analisis 2015 & & & & & &
\end{tabular}

Sumber: Hasil analisis 2015

Keterangan : T1=Padi gogo, T2=Jagung, T3=Sorgum, T4=Ubi kayu, T5=Kacang tanah $\mathrm{S} 1=$ Sangat sesuai, $\mathrm{S} 2=$ =Sesuai, $\mathrm{S} 3=$ Agak sesuai, $\mathrm{N} 1=$ Tidak sesuai saat ini N2=Tidak sesuai selamanya

Tabel 6. Kesesuaian Agroklimat dan Tanah di Kecamatan Kendari pada unit lahan 1

\begin{tabular}{lcccccc}
\hline \multirow{2}{*}{ Faktor Lingkungan } & \multirow{2}{*}{ Nilai } & \multicolumn{5}{c}{ Tanaman } \\
\cline { 3 - 6 } & & $\mathrm{T} 1$ & $\mathrm{~T} 2$ & $\mathrm{~T} 3$ & $\mathrm{~T} 4$ & $\mathrm{~T} 5$ \\
\hline Curah Hujan/tahun $(\mathrm{mm})$ & 1905.8 & $\mathrm{~S} 1$ & $\mathrm{~S} 1$ & $\mathrm{~S} 2$ & $\mathrm{~S} 1$ & $\mathrm{~S} 1$ \\
Bulan Kering/tahun & 4 & $\mathrm{~S} 1$ & $\mathrm{~S} 1$ & $\mathrm{~S} 2$ & $\mathrm{~S} 1$ & $\mathrm{~S} 1$ \\
Kelembaban Udara $(\%)$ & 81.9 & $\mathrm{~S} 1$ & $\mathrm{~S} 1$ & $\mathrm{~S} 2$ & & $\mathrm{~S} 2$ \\
Suhu Udara $\left({ }^{\circ} \mathrm{C}\right)$ & 26.0 & $\mathrm{~S} 1$ & $\mathrm{~S} 1$ & $\mathrm{~S} 1$ & $\mathrm{~S} 1$ & $\mathrm{~S} 1$ \\
$\mathrm{pH}$ & 8.0 & $\mathrm{~S} 3$ & $\mathrm{~S} 3$ & $\mathrm{~S} 3$ & $\mathrm{~S} 3$ & $\mathrm{~S} 3$ \\
$\mathrm{C}$ Organik $(\%)$ & 2.09 (sedang) & $\mathrm{S} 1$ & $\mathrm{~S} 1$ & $\mathrm{~S} 1$ & $\mathrm{~S} 1$ & $\mathrm{~S} 1$ \\
$\mathrm{~N}$ Total $(\%)$ & 0.35 (sedang) & $\mathrm{S} 1$ & $\mathrm{~S} 1$ & $\mathrm{~S} 1$ & & $\mathrm{~S} 1$ \\
$\mathrm{P}_{2} \mathrm{O}_{5}$ Potensial $(\mathrm{mg} / 100 \mathrm{~g})$ & 134 (sangat tinggi) & $\mathrm{S} 1$ & $\mathrm{~S} 1$ & $\mathrm{~S} 1$ & & $\mathrm{~S} 1$ \\
$\mathrm{~K}_{2} \mathrm{O}$ Potensial $(\mathrm{mg} / 100 \mathrm{~g})$ & 194.5 (sangat tinggi) & $\mathrm{S} 1$ & $\mathrm{~S} 1$ & $\mathrm{~S} 1$ & & $\mathrm{~S} 1$ \\
$\mathrm{KTK}$ (cmol/kg) & 18.63 (sedang) & $\mathrm{S} 1$ & $\mathrm{~S} 1$ & $\mathrm{~S} 1$ & $\mathrm{~S} 1$ & $\mathrm{~S} 1$ \\
Kelerengan & $0-3 \%$ & $\mathrm{~S} 1$ & $\mathrm{~S} 1$ & $\mathrm{~S} 1$ & $\mathrm{~S} 1$ & $\mathrm{~S} 1$ \\
\hline Kondisi lahan aktual & & $\mathrm{S} 3$ & $\mathrm{~S} 3$ & $\mathrm{~S} 2$ & $\mathrm{~S} 3$ & $\mathrm{~S} 3$ \\
\hline Kondisi lahan potensial & & $\mathrm{S} 1$ & $\mathrm{~S} 1$ & $\mathrm{~S} 2$ & $\mathrm{~S} 1$ & $\mathrm{~S} 2$ \\
\hline Sumber
\end{tabular}

Sumber : Hasil analisis 2015

Keterangan : $\quad$ T1=Padi gogo, T2=Jagung, T3=Sorgum, T4=Ubi kayu, T5=Kacang tanah $\mathrm{S} 1=$ Sangat sesuai, $\mathrm{S} 2=$ Sesuai, $\mathrm{S} 3=$ Agak sesuai, N1=Tidak sesuai saat ini $\mathrm{N} 2=$ Tidak sesuai selamanya 


\section{J. Berkala Penelitian Agronomi 6 (1) : 9-16 (2018)}

\section{PEMBAHASAN}

Hasil klasifikasi iklim di Kota kendari terdapat dua tipe iklim yaitu tipe iklim D3 dan E2. Pada stasiun pengamatan hujan di Stasiun Meteorologi Maritim Kendari dan Stasiun Geofisika Kendari memiliki tipe iklim D3 sedangkan pada stasiun hujan BPTP Pertanian Kendari memiliki tipe iklim E2. Berdasarkan zona iklim Oldeman dalam Sabaruddin (2012), zona iklim D3 hanya memungkinkan untuk tanaman padi sekali dan palawija sekali tergantung persediaan air. Sedangkan zona iklim E2 tergolong daerahnya terlalu kering me-mungkinkan hanya bisa tanam sekali palawija.

Hasil analisis kondisi agro-klimat untuk pengembangan tanaman menunjukkan variasi, baik antar Kecamatan maupun antar antar tanaman satu dengan tanaman lannya dalam satu kecamatan. Pada kondisi lahan potensial di Kecamatan Baruga pada unit lahan 9 dengan luas 411,02 ha dan unit lahan 10 dengan luas 625,63 ha menunjukkan kondisi agroklimatnya sangat sesuai sampai sesuai. Tanaman padi gogo dan tanaman ubi kayu berada pada kondisi sangat sesuai untuk dikembangkan sedangkan tanaman sorgum, jagung dan kacang tanah berada pada kondisi sesuai. Perbedaan kondisi ini disebabkan terdapat faktor pembatas yang meliputi curah hujan, suhu udara dan kelembaban udara. Pada Tabel 2 dan 3 menunjukkan faktor pembatas untuk tanaman jagung adalah suhu udara sedangakan untuk sorgum yang menjadi faktor pembatas adalah curah hujan dan kelembaban udara. Untuk kacang tanah yang menjadi faktor pembatas adalah kelembaban. Pada kondisi lahan potensial di Kecamatan Puuwatu pada pada unit lahan 26 dengan luas 444,76 ha dan unit lahan 27 dengan luas 404,88 ha menun-jukkan kondisi agroklimatnya sangat sesuai sampai sesuai. Tanaman padi gogo dan tanaman ubi kayu berada pada kondisi sangat sesuai untuk dikembangkan sedangkan tanaman sorgum, jagung dan kacang tanah berada pada kondisi sesuai. Perbedaan kondisi ini disebabkan terdapat faktor pembatas yang meliputi curah hujan, suhu udara dan kelembaban udara. Pada Tabel 4 dan 5 menunjukkan faktor pembatas untuk tanaman jagung adalah suhu udara sedangakan untuk sorgum yang menjadi faktor pembatas adalah curah hujan, lama periode kering dan kelembaban udara. Untuk kacang tanah yang menjadi faktor pembatas adalah kelembaban.

Pada kondisi lahan potensial Kecamatan Kendari pada unit lahan 1 dengan luas 66,66 ha menunjukkan kondisi agroklimatnya sanagat sesuai sampai sesuai. Tanaman padi gogo, jagung dan tanaman ubi kayu berada pada kondisi sangat sesuai untuk dikembangkan sedangkan tanaman sorgum dan kacang tanah berada pada kondisi sesuai. Perbedaan kondisi ini disebab-kan terdapat faktor pembatas yang meliputi curah hujan, periode bulan kering dan kelembaban udara. Pada Tabel 6 menunjukkan faktor pembatas untuk tanaman sorgum adalah curah hujan, lama periode kering dan kelembaban udara sedangkan kacang tanah yang menjadi faktor pembatas adalah kelembaban.

Hasil analisis kondisi tanah untuk pengembangan tanaman menun-jukkan variasi, baik antar kecamatan maupun antar tanaman satu dengan tanaman lannya dalam satu kecamatan. Variasi kondisi ini disebabkan karena kondisi tanah dan kebutuhan hara berbeda antara satu tanaman dengan tanaman yang lainnya. Pada kondisi aktual di Kecamatan Baruga, Puuwatu, dan Kendari menunjukkan kondisi tanah agak sesuai sampai tidak sesuai untuk saat ini. Sedangkan pada kondisi potensial di Kecamatan Baruga, Puuwatu, dan Kendari menunjukkan kondisi sangat sesuai (Tabel 2-6). Kondisi tanah bukan merupakan suatu faktor pembatas utama dalam melakukan pengem-bangan tanaman. Pada tanah dengan kondisi hara rendah dapat diperbaiki dengan pemupukan dan penambahan bahan organik. Pada $\mathrm{pH}$ tanah yang rendah dapat diperbaiki dengan pengapuran sedangkan pada $\mathrm{pH}$ tinggi dapat diturunkan dengan pemberian bahan organik.

\section{Kesimpulan}

Kesesuaian tanaman terhadap kondisi iklim berkisar antara sangat sesuai (S1) sampai dengan agak sesuai (S3), kesesuaian terhadap kondisi fisik dan kimia tanah berkisar antara sangat sesuai (S1) sampai dengan tidak sesuai (N2). Lahan di Kendari untuk budidaya tanaman direkomendasikan untuk pengembangan tanaman padi mencapai 13.219,93 ha, untuk jagung mencapai $10.753,60$ ha, untuk sorghum mencapai 13.219,93 ha, untuk ubi kayu 13.689,41 ha, dan untuk kacang tanah 13.219,93 ha.

\section{Daftar Pustaka}

Djufry, F. 2012. Water balance modelling to estimate the surplus and water deficit in merauke district of papua. J. Informatika Pertanian., Vol. 21 No. 1 p. 1-9

Hidayat, T. Y. Koesmaryono, A. Pramudia. 2006. Analysis of Water Balance for Determine Growing Periods Potency of Food Crops in Banten Province. J. Floratek. Vol.2 p. 55-62

Tjasyono, B. 2004. Klimatologi. ITB. Edisi kedua. Bandung 
J. Berkala Penelitian Agronomi 6 (1) : 9 - 16 (2018)

Tjasyono, B. 1999. Klimatologi Umum. ITB. Suciantini. 2015. Relationship between climate Bandung

Sabaruddin, L. 2012. Agroklimatologi: Aspekaspek Klimatik untuk Sistem Budidaya Tanaman. Alfabeta. Bandung (rainfall) and crop production in Pacitan. Prosiding Seminar Nasional Masyarakat Biodiv. Indonesia. Vol. 1, No.2 p. 358-365 